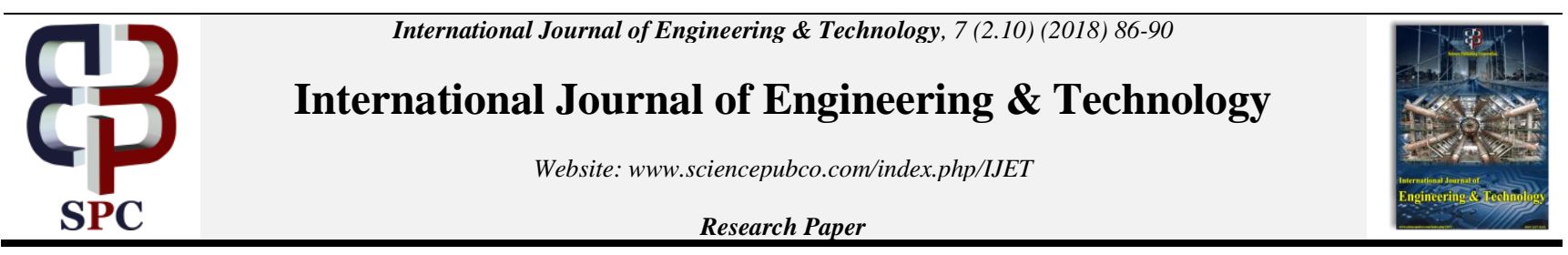

\title{
Capital utilization for livelihoods among rural fishing migrant households in the origin area
}

\author{
Nattapon Meekaew ${ }^{1 *}$, Dusadee Ayuwat ${ }^{2}$ \\ ${ }^{1}$ Faculty of Humanities and Social Sciences, Khon Kaen University, Labor and International Migration Service Center \\ ${ }^{2}$ Department of Sociology and Anthropology, Faculty of Humanities and Social Sciences, Khon Kaen University, Labour and Interna- \\ tional Migration Service Center \\ *Corresponding author E-mail: nattaponmeekaew@gmail.com
}

\begin{abstract}
This research paper aims to analyze the capital utilized for livelihoods among the fishing migrant households in the origin area. A qualitative methodological approach, specifically a phenomenological approach was applied in the study, with in-depth interview and participatory observation employed as research tools. Twenty fishing migrant households, located in Bah sub-district, Surin province were selected as the target of the study; the data collection period was during January to June 2017. The research results explored the variety of capital that the fishing migrant households utilized for their livelihoods. The households created their livelihood strategies based on the capital they possessed. The five categories of capital that were identified as resources for creating livelihood strategies included 1) financial capital, which the households used to make life choices in the form of savings and land accumulation, 2) human capital, which was in the form of knowledge and experience applied in their careers in order to sustain the household life. 3) Social capital, which was used to solve household problems, for instance, tracking household members who were missing during fishing work, or participating in community activity, and 4) natural capital and physical capital, which were used as a mechanism in striving to make a living, for instance, collecting wild food items, or using natural materials to construct a house.
\end{abstract}

Keywords: Livelihoods, Capital, Capital Utilization, Household in The Origin Area, Fishing Industry

\section{Introduction}

For decades, Thailand's development policy has focused on economic development in order to serve capitalism-based production. The policy impacted upon people around the country, especially those in rural areas. The changes in rural areas caused structural problems in both the community and in rural households. The structural problems that people in rural areas encountered mostly related to poverty and the vulnerability of their livelihoods, for instance, natural disasters, geography-related problems, and improper government policy implemented in rural society [1]. Thus, rural people had to find their own ways to secure their household's livelihood, and migration became an opening for rural people to try to break free of poverty.

Migration is a social phenomenon which has been established in the people of the northeast of Thailand for decades and has been generally used as a mechanism for developing a household's ability to deal with difficult living conditions, especially economic conditions [2]. The issue of migration arose because rural households suffered from limited living resources, and could not manage them appropriately. Thus, many of the northeast people chose to migrate from their home area to seek a better life. According to migration statistics in 2016, the number of migrants in Thailand is estimated at 8,900,000. Within these numbers, 2,960,000 of the migrants are considered to have originated from the northeast region, representing $32.9 \%$ of the country's total migrants [3]. It was reported that some northeastern migrants chose to work as construction workers in urban areas, while many of them worked in the marine fishing industry, which has a high demand for workers. Northeastern households sent a large number of their members to work in the fishing industry with the hope of improving their standard of living.

Marine fishing provided a large amount of remittance to the households in the place of origin, with many of the households achieving a higher economic status. However, fishing work was reported as being a dangerous job. Migrant fishing workers encountered unpredictable risks such as exposure to drug addiction, abduction, forced labor, physical and mental abuse, discrimination, and wage oppression. These problems have lately been considered as a part of the human trafficking issues that strongly affect Thailand's fishing industry, internationally $[4,5]$. These issues have inevitably affected both the fishing workers and their households due to the fishing workers being the main labor force generating income for households in their places of origin.

Therefore, the fishing migrant households have had to find livelihood strategies, utilizing various types of household resources, to provide incomes other than only from fishing work. This paper analyzes the utilization of capital for livelihoods among the fishing migrant households at their places of origin. The results of the study may contribute to the fishing migrant households securing the sustainability of their livelihoods, and provide a better livelihood guideline to the fishing migrant households.

\section{Materials and methods}

This research applied the concept of capital [6] as a key concept to explore the livelihoods of the fishing migrant households at their places of origin. The concept of capital considers an interdiscipli- 
nary concept, generally used in economics, in terms of production, stocks, and yields. Economic capital, therefore, refers to the various kinds of assets that generate revenue for the resource owners [7]. In addition, capital is also property produced by labor forces [8]. Marx analyzed capital in the form of surplus value. The surplus value and force value were considered equally, and were made up from the cost of labor. Marx mentioned it was a way that the capitalists used to exploit workers, and finally the exploitation resulted in a class struggle between the capitalists and the workers who attempted to take advantage from the surplus value. Karl Polanyi ${ }^{9}$ debated the use of the economics view in analyzing capital utilization, which focused only on the labor force, land, and money. Polanyi considered capital as a fictitious commodity or an invented commodity that did not exist. That is to say that the labor force is embedded in the human being. Land is just an object that humans seek as an advantage from nature, and money is just a substitute object for exchanges that do not produce any output [9]. Therefore, for the study of capital it is essential to focus on anything in nature, other than the economic view.

This research focused on capital, based on a concept of livelihoods [6], in which the fishing migrant households, at the places of origin, implemented in their household activities. The capital comprised of five types including; financial capital, human capital, social capital, natural capital, and physical capital [6]. All of these types of capital were utilized by the fishing migrant households in order to create their own livelihood strategies.

Qualitative methodological approach, specifically phenomenological approach [10], was implemented in the study to investigate the capital used to secure the livelihoods among the fishing migrant households. The units of analysis were community and household. The key informants of the study consisted of five community leaders, five senior citizens in the community, and twenty representatives of the fishing migrant households whose household members had worked in the fishing industry for at least 5 years. The research area was a community in Bha Sub-district, Tha Tum District in Surin Province. A snowball sampling technique was implemented to select the fishing migrant households [11]. In-depth interview was used to collect field data from the household representatives, while participatory observation was used to observe household activities. The triangulation method was implemented for the accuracy of the data, and content analysis was used to analyze data [12]. Data collection was conducted during January to June 2017.

\section{Results}

\subsection{Contexts of community and the fishing migrant households}

Bah community is a rural community located in Tung Kula Rong Hai paddy field, a hub of the premium Jasmine rice fields in Thailand. Bah community is an agricultural community located along the Mun River. The geographical area is suitable for farming so most of the villagers have conducted rice farming as a main occupation, for centuries. However, a limitation to the amount of landholding has resulted in the villagers producing less household income, which proved insufficient for household livelihoods. Some households have additional incomes from producing handicraft works, such as fishing nets, but the production is limited to the farming off-season. In addition, the Provincial Governmental Agencies implemented development projects aimed to improve the well-being of people in the community, but the projects were not encouraged and supported by the local people. This brought about a struggle for the households to sustain their livelihoods. People in the community, therefore, decided to migrate to work in urban areas such as Surin town or in industrial locations such as Bangkok, Rayong, and Chonburi provinces; taking up work in construction, and the marine fishing industry, which could provide satisfactory incomes for their households.

With regard to the characteristics of a typical fishing migrant household, members of a fishing migrant household were mostly male and aged between 25-55 years old. Most fishing migrants were aged over 40 years old, and would have worked in the fishing industry for 10-20 years. Workers mostly migrated to take part in marine fishing in the southern provinces of Satun and Songkhla. and the remittance they were able to send back to their households amounted to between USD250-500 per month. Some households received a remittance of more than USD800, these being the fishing migrants who worked on the small-sized fishing vessels which employed a smaller fishing crew. Those who worked on the smallsized fishing vessels could sell fish and they received a larger amount of commission. Furthermore, the small fishing vessels were generally operating in coastal fishing, so the vessels would return to shore to sell their catch more often than the larger vessels, which focused on deep-sea fishing in international waters.

Marine fishing was introduced to the villagers in Bah community during 1977 and this occupation effectively changed the ways of life of the people in the community. Marine fishing improved the living standards of the fishing migrant households, since the occupation provided a more sufficient income for them. The workers could send remittances to their households easily, and then they could use the funds for household activities, for instance, buying agricultural tools to aid their production.

However, some fishing migrant households were unable to manage their remittances effectively. They spent the money on activities that were of no benefit to their households, for instance, spending on luxury goods such as clothes, watches, gambling, etc. Consequently, they were unable to escape from poverty. Although sending household members to be workers in the fishing industry would be an option to secure their livelihood, some households received differing outcomes from the fishing work. These outcomes can be categorized into three types as follows:

1) The successful households; these households had a comfortable life as they received regular remittances from their household members. The money was used for savings or investing for the household, such as for buying land. In addition, these households had a good relationship with the community. They lived peacefully in their neighborhoods. These households also had the opportunity to meet up with their fishing migrants regularly, so maintaining a good relationship within the family

2) The unpredictable households; these households had a good living in the same way as the first group. The household members often sent remittances back, but less frequently than the first group. For instance, they sent their remittance back every three months. Therefore, the family members at home were still struggling to live. In addition, some households, although receiving their remittance, could not manage their money properly. For instance, they would buy extravagant items such as brand-name clothing, cell phones, or gamble. That is to say that they did not manage the household income by investing in other household activities.

3) The struggling households; these were the households that experienced negative effects from the migration experience. The living conditions of this group were quite difficult, since they did not receive remittances from their household members. Some fishing migrant household members experienced negative working conditions, for instance, physical harassment, suffering an accident during work, or even disappearing at sea. These problems caused difficulties for their families remaining in their places of origin. 


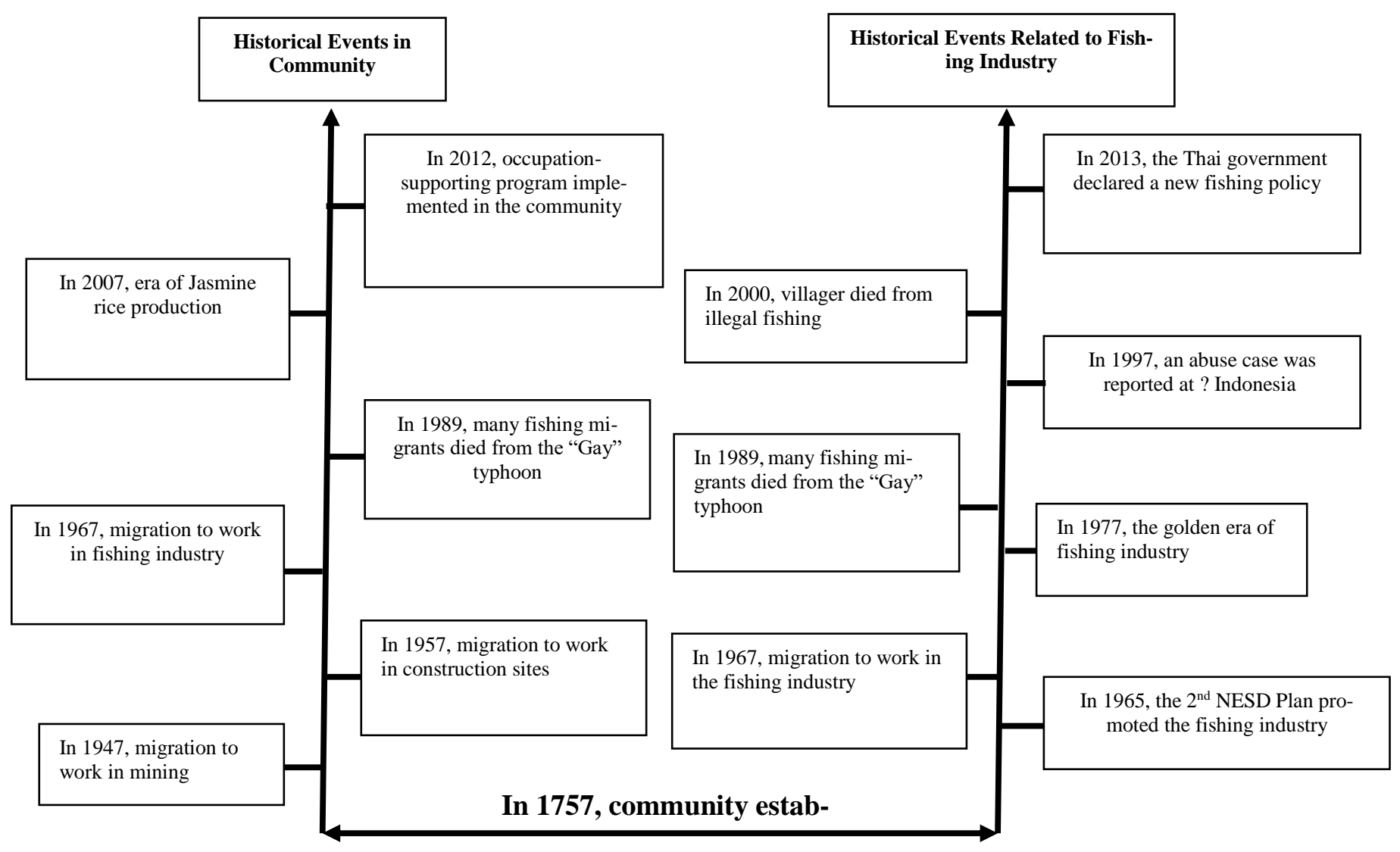

\subsection{Capital utilization of livelihoods among rural fish- ing migrant households in the origin area}

The migration of family members into the marine fishing industry caused the households in their places of origin to change their livelihoods. These households, therefore, had to create different livelihood strategies that were in accordance with their resources. The livelihood strategies of the migrant fishing households may be analyzed through the relationship between livelihood strategies and household capital [6], details as follows:

Capital utilization for savings and land accumulation; financial capital became the key capital used by the fishing migrant households to sustain their livelihoods. The financial capital took the form of household savings and capital accumulation was used to achieve livelihood goals. The remittances from marine fishing activities were the primary source of funds that supported the financial status of the households because most households, at the places of origin, could not generate sufficient household income due to limitations of land holding or their inability to have a career within the community. The amount of remittance that fishing migrant workers sent to their households was mostly deducted from their salary and the commissions from the sale of the catch, which was approximately 1 percent of the total fish sold.

The remittance was mostly used for household consumption expenses, such as, food, clothing, paying the household bills and education expenses for their children. The households also saved their remittances for future use. In the case of households that received a large amount of remittance, these households often chose to invest their financial capital by acquiring agricultural land. Many households were in need of more land to conduct agricultural activities so they could generate more household income at home. In addition, some households used their financial capital to start their own businesses in order to generate more household income. For instance, numbers of the household may have used their financial capital to create a grocery store, or buy agricultural equipment, such as a tractor, in order to make extra income from agricultural activities. These methods of income generation could be considered as the strategy that the households adopted to have choices in their livelihoods, by utilizing their financial capital. This finding was confirmed by Chiodi and Jaimovich [13] who stated that it was the outcome of migration which had the strongest effect on rural households, and it was considered as an important livelihood strategy for the migrant households. In addition, financial capital, in the form of village fund loans, was an accessible source for the households. However, this source of finance was often used for migration purposes, such as for providing for the expenses of finding work abroad for household members, or for investment in agricultural activities.

Another finding presented in this section is that the fishing migrant households also used other types of capital to support the utilization of financial capital to achieve their goals, for instance, some household members used their knowledge and skills when considering investing in various types of saving account. These skills came about due to the education that the household members had received. The knowledge and skills used could be considered as the human capital that the households used to reduce the risk to their household's financial status. In addition, social capital was another type of capital that the households used by creating a community cooperative network for facilitating access to savings opportunities, or by having good relationships with the people in the community in order to achieve their goal of accumulating land (Table 1).

Capital utilization for conducting career opportunities; this kind of living pattern focused on human capital, which was the fundamental capital that enabled the fishing migrant households to live during the uncertainties of their situation. Human capital was accumulated as skills and experiences from living activities of different contexts. The households of the fishing migrants implemented their human capital in different careers, for instance, their rice farming skills were a fundamental skill that was embedded in 
traditional community production. The location of their community was at the heart of the premium jasmine rice production, so rice farming skills had been transferred from generation to generation. The fishing migrant household members have the knowledge and skills for use in rice farming, growing rice for household consumption. In addition, the community also received support from government agencies to encourage the development of careers in the community, for example, the Development of Livestock Project, and the Integrated Agriculture Training Program. The implementation of these projects could give the households full access to the knowledge and skills required for career development. Many fishing migrant households were able to experience the career supporting programs as implemented by the government agencies. Some households developed their own skills, for instance, they started cultivating organic vegetables in their fields during the rice farming off-season, or found employment by taking on contract sewing for the textile factory, etc. The career supporting programs encouraged the households to create their own careers, and increased their household income beyond relying on remittance only. In addition, it was found that some fishing migrant households also transferred their skills between the household members, internally. Members of the fishing migrant household may be taught skills by their returning fishermen household members. For instance, they may be shown a technique for food processing that had been learned during seafood processing work at sea. By using these new skills, the household members could produce processed foods for the local community, and so were able to generate further income. The findings were confirmed by Dustman et al [14] who stated the positive effects on households when sending household members to work abroad.

Improving skills and knowledge through education was another human capital improvement that was presented to the fishing migrant households. The educated members of the household were able to implement their skills and knowledge, gained from education institutions, within their household careers. For instance, some household members learnt automotive skills at the vocational school, so they could apply these skills to open their own motorcycle garage in the community. The money to pay for tuition fees came from the remittance from the fishing work. Therefore, it could be said that human capital was used to develop living skills and knowledge. Although human capital would be an important element for household careers, financial capital was vital for the households to achieve their goals. The financial capital used by the households was a combination of the remittance from the fishing work, community loans, and the implementation of physical capital. For instance, some households would open a store in their own home.

Capital utilization for problem solving and community engagement; social capital is the primary capital used to help give the fishing migrant households access to opportunities and social roles in the community. Social capital is based on the concept of livelihood and refers to the networks and relationships created by social structures and social relationships among the actors. The main purpose of social capital implementation was to create social networks in order to solve household problems, for instance, household disputes, or the tracking down of community members who went missing from their fishing activities; by using personal relationships between household members and government officials, these problems could be resolved. Therefore, the social network was the capital derived from a social structure based on the same ethnic identity which later resulted in a larger social network within the area. Social networks found in the community were founded on a patron-client relationship, for instance, having household members working in local organizations. There were also horizontal relationships, for instance, neighbors borrowing household consumption goods, or cooperation in household activities such as rice cultivation, raising silk worms, etc. Furthermore, social capital created by the fishing migrant households also facilitated access to resources in the community, such as access to community jobs, by using the influence of the household background or migratory-based relationships among the households in the community. Therefore, it could be said that social capital served as both key capital and supplementary capital for livelihoods, and that enabled the households to get through any difficult situations in the community.

Capital utilization for household survival; this livelihood pattern focused on physical capital and natural capital that correlated to each other. Physical capital refers to resources created for household-based production and infrastructure development for increasing the natural capital, such as the construction of an irrigation system. The fishing migrant households got benefits from physical capital within the community by deriving from the financial capital and human capital of their own households, or by using benefits from public infrastructure, for instance, using an irrigation canal for their rice farming. However, the use of physical capital in the community was limited due to the limited availability of physical resources in the area; for instance, the irrigation system consisted of only a single line irrigation canal, the canal did not cover all the farm areas in community. Much of the farmland was unable to access the benefits of the irrigation canal, and this led to insufficient production yields and low income for the affected households.

In addition, access to updated information was another essential form of physical capital for the fishing migrant households, especially access to information regarding social benefits that the households may be able to receive. Information related to the fishing activities of their household members, in order to maintain the rights and welfare of their household members was also important. With regard to struggling households or groups with limited access to other forms of capital, natural capital played an important role in helping these households survive, such as the use of natural foods gathered from the forest, etc. Natural capital was to be found in the area in form of herbs, mushrooms, vegetables, as well as natural water sources. These findings reflected the relationship between physical capital and natural capital that supported each other, and helped the households to survive [15].

Table 1: Summary of Capital Utilization into Livelihoods among Rural Fishing Migrant Households

\begin{tabular}{|c|c|c|c|c|c|c|}
\hline \multirow[b]{2}{*}{ Capital Utilization } & \multirow[b]{2}{*}{ Primary Capital } & \multicolumn{5}{|c|}{ Secondary capital } \\
\hline & & $\begin{array}{l}\text { Financial } \\
\text { Capital }\end{array}$ & $\begin{array}{l}\text { Human } \\
\text { Capital }\end{array}$ & $\begin{array}{c}\text { Social } \\
\text { Capital }\end{array}$ & $\begin{array}{l}\text { Physical } \\
\text { Capital }\end{array}$ & $\begin{array}{l}\text { Natural } \\
\text { Capital }\end{array}$ \\
\hline $\begin{array}{l}\text { 1) Capital utilized for savings and } \\
\text { land accumulation }\end{array}$ & Financial capital & $\sqrt{ }$ & $\sqrt{ }$ & $\sqrt{ }$ & & \\
\hline $\begin{array}{l}\text { 2) Capital utilized for career op- } \\
\text { portunities }\end{array}$ & Human capital & $\sqrt{ }$ & $\sqrt{ }$ & $\sqrt{ }$ & & \\
\hline $\begin{array}{l}\text { 3) Capital utilized for problem } \\
\text { solving and community engage- } \\
\text { ment }\end{array}$ & Social capital & & $\sqrt{ }$ & $\sqrt{ }$ & & \\
\hline $\begin{array}{l}\text { 4) Capital utilized for household } \\
\text { survival }\end{array}$ & $\begin{array}{l}\text { Natural capital } \\
\text { and physical } \\
\text { capital }\end{array}$ & & & $\sqrt{ }$ & $\sqrt{ }$ & $\sqrt{ }$ \\
\hline
\end{tabular}




\section{Discussion}

Livelihood strategies of the fishing migrant households, at their places of origin, are formed by the variety of capital that the households owned and utilized. Recent studies on livelihood strategies have given priority to life choices which view the households as the active agents who independently decide their own strategies in line with the socio-cultural context. ${ }^{1}$ However, in the fishing migrant household context, livelihood strategy is formed in order to enable the households to survive, especially if the households experienced poor outcomes from the fishing work. The construction of a livelihood strategy based on a "survival" strategy is confirmed by Hunter et al. [16], who emphasized the need for reliance on natural resources in order to sustain household livelihoods in rural areas.

Capital utilization for those living among the fishing migran households is not only focused on a single type of capital, but on others also, used to support the primary capital in order to achieve the livelihood goals. Each type of capital is implemented to supplement other types of capital and leads to the creation of a proper livelihood strategy for their own household [17]. Examples would be the implementation of financial capital and human capital to create a living choice, or implementing social capital to support access to physical capital. The findings confirmed Dustmann et al. ${ }^{14}$ and Phongsiri [18], who discussed the importance of integrating capital for dealing with the dynamics in a social structure context. In addition, it was found that the degrees of capital utilized are quite different, although the forms of capital utilized are similar to each other. The result is each household has different livelihood outcomes, which also reflects the variety of livelihood strategies that the fishing migrant households select to deal with different contexts.

The findings also indicate that social capital plays an important role in accessing various types of resources. Social capital is presented in this paper as a view of the social networks among households in the community which are constructed based on the kinship system and ethnic consciousness. Therefore, the fishing migrant households maintain close relationships with their neighboring households by, for instance, sharing food, conducting rice farming together, or dealing with disputes among community members. These findings reflect that social networking is a critical condition for household livelihoods. Having a good social network could enable the fishing migrant households to create strategies to improve their livelihoods $[18,19]$. In addition, the access to capital is closely related to power. Power becomes an important resource to access capital, and is embed in relationships between individuals, households, communities, or government agencies. Baumann ${ }^{20}$ confirmed the existence of power relations in livelihood strategy construction. Every relationship in capital accessibility is formed, and related to power. Therefore, the power relation is defined as the "political capital which provides access to other capital $[17,18,20,21]$ and finally creates the sustainability of capital utilization among the households.

The results of this paper could be implemented as a policy recommendation to create a mechanism to assist the fishing migrant households, especially those households that suffer from poor living conditions, so as to develop their livelihoods properly. The results of this study could help this household group to have choices in implementing their capital for a livelihood strategy. Finally, although the findings of this study present the variety of capital used to sustain the livelihoods among the fishing migrant households, it is necessary to conduct further study regarding livelihood security among the fishing migrant households in order to explore the measuring tools to examine the factors that influence the level of livelihood security among the fishing migrant households.

\section{Acknowlegdement}

This paper is a part of a dissertation entitled, "Livelihood Security among Households at Places of Origin of ESAN Migrants in the Fishing Industry", the PhD Program in Sociology, Department of Sociology and Anthropology, Faculty of Humanities and Social Sciences, Khon Kaen University, Khon Kaen, Thailand. The researcher would like to thank the Department of Sociology and Anthropology, Faculty of Humanities and Social Sciences, Khon Kaen University for academic support and also the Research and Training Center for Enhancing Quality of Life of Working Age People for both academic and financial support. Finally, sincere gratitude is extended to all key informants especially the fishing migrant households who participated and provided useful information for this paper.

\section{References}

[1] Chambers R \& Conway GR (2005), 'Ideas for Development', London: Earthscan.

[2] Ayuwat D \& Chamaratana T (2014), 'The role of labor broker networks in setting the price of working abroad for Thai migrant workers', Asia-Pacific Population Journal 28(4), 51-68.

[3] National Bureau of Statistics (2016), 'The Migration Survey', Available: http://service.nso.go.th/nso/web/survey.

[4] Chantavanich S, Laodumrongchai S \& Stringer CS (2016), 'Under the Shadow: Forced Labour Among Sea Fishers in Thailand', Marine Policy 68, 1-7.

[5] International Labour Organization (2013), 'Employment Practices and Working Conditions in Thailand's Fishing Sector' Bangkok: ILO.

[6] DFID (1999), 'Sustainable Livelihoods Guidance Sheets', London: Department for International Development (DFID)

[7] Fama EF \& Miller MH (1972), 'The Theory of Finance', Hinsdale, Illinois: Dryden Press.

[8] Marx K (1972), 'Capital: A Critique of Political Economy Vol.1', (B. Fowkes, Trans.), Middlesex: Penguin Book.

[9] Polanyi K (1977), “The Livelihood of Man', (H.W. Pearson, $E d$.), New York: Academic Press.

[10] Moustakas C (1994), 'Phenomenological Research Method', Thousand Oaks, Calif: SAGE Publications.

[11] Voicu MC (2011), 'Using the Snowball Method in Marketing Research on Hidden Populations', Challenges of the Knowledge Society, 1, 1341-1351.

[12] Hsieh HF \& Shannon SE (2005), 'Three Approaches to Qualitative Content Analysis', Qualitative Health Research 15(9), 1277-1288.

[13] Chiodi V, Jaimovich E \& Rojas GM (2012), 'Migration, Remittances and Capital Accumulation: Evidence from Rural Mexico', The Journal of Development Studies 48(8), 1139-1155.

[14] Dustmann C, Fadlon I \& Weiss Y (2011), 'Return Migration, Human Capital Accumulation and the Brain Drain', Journal of Development Economics 95(1), 58-67.

[15] Stijns JP (2006), 'Natural Resource Abundance and Human Capital Accumulation', World Development 34(6), 1060-1083.

[16] Hunter LM, Nawrotzki R, Leyk S, Maclaurin GJ, Twine W, Collinson M \& Erasmus B (2013), 'Rural Outmigration, Natural Capital, and Livelihoods in South Africa', Population, Space, and Place 20(5), 402-420.

[17] Sen A (2005), 'Human Rights and Capabilities', Journal of Human Development 6(2), 151-166.

[18] Phongsiri M (2015), 'Thai Diaspora and Sustainable Livelihood Strategies', Khon Kaen: Khon Kaen University.

[19] Emerson R (1976), 'Social Exchange Theory', Annual Review of Sociology 2, 335-362.

[20] Baumann P (2000), 'Sustainable Livelihoods and Political Capital: Arguments and Evidence from Decentralization and Natural Resource Management in India', (Working paper 136). London: Overseas Development Institute

[21] Nee V \& Opper S (2010), 'Political Capital in a Market Economy’, Social Forces 88(5), 2105-2132. 